\title{
Synergy and Harmony of the Presidential System of Multi Parties and Election to Associate Indonesia 2045
}

\author{
Dody Nur Andriyan ${ }^{1}$ \\ Constitutional of Law Department, Institut Agama Islam Negeri Purwokerto - \\ Indonesia
}

\begin{abstract}
One of the agendas and results of the I-IV Amendment to the 1945 Constitution is to strengthen the Presidential system. Strengthening the presidential system synergized with reforming the party and election system must be carried out in order to achieve the objectives of governance and institutions in the framework of Indonesia 2045. The 2019 elections are simultaneously legislative and presidential elections as stipulated in Law Number 7 of 2017 concerning General Elections. The purpose of this article, the first simultaneous election should be legislative, presidential and regional head elections simultaneously. Secondly, there are 4 (four) objectives: 1). Effectiveness and efficiency, 2). Righteous democracy, 3). creating a solid and effective government, 4). period (periodization) that is more organized. Using the optics of constitutional law studies, and socio-legal, strengthened and enriched historical studies of presidential, party and election systems in Indonesia and comparisons with the United States, Brazil, Argentina.

There are seven recommended strategies offered in the article: 1) Synergizing the Presidential Election, Legislative Elections and Regional Head Elections simultaneously in 2029, 2) Preparing the Draft Law for Regional Head Election Courts, 3) Making a blue print of the Presidential Institution Bill, 4). Simplify party systems with an electoral threshold, 5). Simplify the number of parties in parliament with parliamentary threshold, 6). Implement a threshold presidential order to create balance in a multi-party presidential system, 7). Make changes to the Election Law and Evaluate the Proposal Election system with the Sainte-Laguë calculation method.
\end{abstract}

Keywords: Presidential, Multiparty, Concurrent Election, Indonesia 2045

\footnotetext{
${ }^{1}$ Dody Nur Andriyan is a Constitutional of Law Lecturer and Researchers at the Center for Constitutional Studies and Regional Policy, Management of the Association of Constitutional Law Lecturer and State Administrative Law. E-mail: dodylaw@gmail.com
} 


\section{Sinergi dan Harmoni Sistem Presidensial Multi Partai dan Pemilu Serentak untuk Menyongsong Indonesia 2045}

Dody Nur Andriyan

\section{Pendahuluan}

1.1. Latar Belakang

Politik Hukum Sistem Pemerintahan di Indonesia Pasca Amandemen UUD 1945 I - IV yang sudah menyepakati untuk menerapkan sistem presidensial multipartai memang masih menyisakan banyak pekerjaan rumah yang harus diselesaikan. Sistem presidensial multipartai di Indonesia kemudian menyebabkan kekuasaan Presidensial menjadi bias. Sebab sistem multipartai memiliki kecenderungan untuk menitikberatkan kekuasaan pada legislatif, sehingga peran eksekutif menjadi lemah sehingga malah akan cenderung menjadi sistem Parlementer (Khairul Fahmi, 2016:419).

Dalam sistem multipartai apalagi yang dikombinasikan dengan sistem presidensial, maka setiap hasil pemilu akan sangat sulit mencari partai yang memiliki suara yang cukup kuat (mayoritas mutlak) untuk membentuk suatu pemerintahan sendiri. Sehingga tidak ada pilihan lain, partai pemenang pemilu harus berkoalisi dengan partai lainnya, untuk mencegah dan menanggulangi "gangguan" dan "rintangan" dari beberapa partai yang dikalahkan namun memiliki suara dan kursi di DPR. Sistem presidensial yang seharusnya pemimpinnya (Presiden) sebagai eksekutif yang tidak dapat dipengaruhi oleh legislatif dan dapat sesegera mungkin membuat program kerja dan menjalankan roda pemerintahan, malah kemudian lebih disibukkan untuk membentuk koalisi dengan partai lain untuk membentuk kabinet. Sehingga sistem presidensial multipartai di Indonesia ini kemudian menimbulkan anomali Andriyan, 2016: 8-10).

Sejalan dengan hal tersebut, Badan Perencanaan Pembangunan Nasional (Bappenas) telah menyusun agenda menyongsong Indonesia 2045 yang salah satunya adalah bidang politik dalam negeri terkait dengan kelembagaan yang ideal untuk meningkatkan ketahanan nasional dan tata kelola pemerintahan terutama dalam sektor reformasi ketatanegaraan (presidensial parlementer). Sebagaimana dijelaskan dalam visi Indonesia 2045, ada tiga hal yang sangat relevan terkait makalah ini: pertama, adalah pemantapan Undang-Undang Politik, utamanya peran lembaga perwakilan dan presiden. Kedua, Lembaga Perwakilan yang efektif baik secara struktur maupun fungsi menyalurkan aspirasi dan saling kontrol (check and balance) Ketiga, 
sistem Presidensial yang diharapkan adalah yang kuat, efektif dan akuntabel (Menteri PPN/Bappenas, 2017: 69).

Sebagaimana sudah di uraikan oleh Penulis dalam buku Hukum Tata Negara dan Sistem Politik: Kombinasi Presidensial dengan Multipartai di Indonesia, pilihan sistem presidensial multipartai yang sudah disepakati tersebut, harus di siasati dengan menggelar Pemilu Serentak. Keserentakan pemilu mengandung banyak peluang untuk bisa menyinergikan sistem pemerintahan presidensial dengan sistem multipartai (Andriyan, 2016:232). Oleh karenanya agenda yang harus disegerakan adalah melakukan sinergi antara penguatan sistem presidensial dengan pembenahan sistem pemilu serentak. Hal tersebut senada dan sejalan dengan Putusan Mahkamah Konstitusi Nomor 14/PUU-XI/2013 bahwa dengan dilaksanakan Pemilihan Presiden dan Pemilihan Legislatif secara serentak pada waktu bersamaan, maka akan memperkuat dan membuat stabil sistem presidensial multipartai. Selain itu akan menimbulkan efisiensi dan efektivitas baik dari segi waktu, tenaga, anggaran dan regulasi.

\subsection{Permasalahan}

Bagaimanakah strategi yang dilakukan untuk menciptakan sinergi dan harmoni presidensial multipartai dengan pemilu serentak dalam rangka menyongsong Indonesia 2045?

\subsection{Kerangka Berpikir}

Di dalam artikel ini diberikan gambaran dan pemahaman tentang sistem presidensial multipartai yang ada di Indonesia. Sekaligus beberapa landasan, gambaran dan rekomendasi bahwa pemilu serentak seharusnya juga pemilu legislatif, presiden dan kepala daerah secara serentak. Lebih lanjut artikel ini juga memberikan ide, gagasan dan rekomendasi untuk menciptakan sinergi dan harmoni presidensial multipartai dengan pemilu serentak dalam rangka menyongsong Indonesia 2045.

Artikel ini memiliki manfaat teoritis memberikan dan memperkaya spektrum cakrawala keilmuan tentang Hukum Tata Negara yang sangat berkaitan erat dengan Ilmu Politik dan Ilmu Pemerintahan. Sekaligus memberi sumbangsih teori ketatanegaraan dan sistem pemerintahan yang betul-betul khas Indonesia. Selain itu artikel ini juga memberi manfaat praktis yaitu masukan pada praktisi, politisi, pemerintahan dan pemangku kepentingan terkait strategi dalam rangka untuk pemantapan undang-undang politik, peran lembaga perwakilan dan presiden, efektivitas lembaga perwakilan baik fungsi maupun kontrol dan penguatan sistem presidensial dalam rangka Visi Indonesia 2045 
II. Tinjauan Literatur

\subsection{Sistem Presidensial Multipartai}

Berawal dan bermula dari karya penulis berupa Buku berjudul Hukum Tata Negara dan Sistem Politik: Kombinasi Presidensial dengan multipartai di Indonesia, di dalam karya tersebut penulis menjabarkan bahwa problematika kombinasi sistem presidensial dengan sistem multipartai yang terjadi di Indonesia harus diantisipasi dengan beberapa model strategi reformasi ketatanegaraan (Andriyan, 2016:196). Beberapa model strategi reformasi ketatanegaraan dimaksud akan dijelaskan lebih lanjut di Bab Pembahasan.

Sistem presidensial menyimpan beberapa kelemahan mendasar yang akan menimbulkan problematika. Kelemahan pertama, adalah masalah kemandekan atau konflik antara eksekutif dan legislatif yang bisa mengakibatkan "jalan buntu" dan "kelumpuhan" yang diakibatkan karena akibat dari ko-eksistensi dari lembaga eksekutif dan legislatif (Hanan, 2016:1453). Dalam sistem Presidensial bila terdapat pertentangan antara kedua badan ini, maka tidak ada sumber daya institusional untuk memecahkannya. Beda dengan sistem Parlementer yang terdapat mosi tidak percaya untuk tetap menjaga eksekutif dan legislatif sejalan dalam sistem parlementer (Andriyan, 2016:81). Solusi yang dikemukakan oleh Komite Sistem Konstitusi adalah dengan menyelenggarakan pemilu presiden dan pemilu legislatif secara bersamaan atau serentak pada satu waktu dan dengan mendorong pemungutan suara langsung sebanyak mungkin, dengan mencegah golongan putih (golongan yang tidak mau memberikan suara) dengan cara-cara yang demokratis tanpa paksaan (Komite Sistem Kenegaraan, 1995:21).

Kekurangan yang Kedua, dalam sistem Presidensial adalah kekakuan temporal. Juan Linz menulis bahwa masa jabatan presiden yang pasti menguraikan periode-periode yang dibatasi secara kaku dan tidak berkelanjutan, sehingga tidak memberikan kesempatan untuk melakukan berbagai penyesuaian yang dikehendaki oleh keadaan (Andriyan, 2016:128). Artinya Linz mengungkapkan bahwa pembatasan masa jabatan justru menimbulkan kelemahan yaitu program pemerintah yang baik dan bagus untuk masyarakat belum tentu di lanjutkan oleh presiden selanjutnya, mengingat terbatasnya masa jabatan presiden (Hanan, 2016:1453). Solusi yang coba ditawarkan adalah dengan cara Parlemen membuat sebuah program peta jalan (road map program) yang merupakan blue print bagi pembangunan dan program bagi bangsa dan negara kedepan. Sehingga siapapun yang berkuasa mau tidak mau harus melaksanakan blue print tersebut.

Kelemahan Ketiga, dari sistem pemerintahan presidensial adalah bahwa sistem ini berjalan atas dasar aturan "winner takes all" atau pemenang menguasai semuanya yang cenderung membuat demokrasi menjadi ajang permainan dengan semua potensi konfliknya (Andriyan, 2016:129). Politik menjadi eksklusif bukan inklusif dan politik akan menjadi sumber malapetaka 
perpecahan bukan untuk mengagregasikan dan menyatukan sebuah bangsa dan negara (Lijphart, 1995:22). Solusi yang diajukan adalah dengan mengadakan pemilu presiden dengan dua tahap pemungutan suara. Hal ini untuk mencegah terjadinya minority winner takes all. Sebab dengan mengadakan putaran kedua, bisa terjadi perubahan peta politik dengan bergabungnya pihak yang kalah pada putaran pertama kepada pihak lain di putaran kedua. Sehingga legitimasi dapat lebih optimal dan berubah menjadi mayority takes all(Lijphart, 1995:22).

\subsection{Pemilihan Umum Serentak}

Pada saat dahulu dilakukan Amandemen I-IV UUD 1945, selain kesepakatan tentang Pemilu Serentak juga muncul kesepakatan mengenai sistem bicameralism di sistem parlemen Indonesia dengan munculnya lembaga DPD (Dewan Perwakilan Daerah). ${ }^{2}$

Terdapat 6 (enam) alasan argumentatif, terkait pemilu serentak yang menjadi dasar pijakan dilakukannya Pemilu Serentak, sebagaimana termaktub di dalam Putusan Mahkamah Konstitusi Nomor 14/PUU-XI/2013 (Nazriyah, 2015:117-118) antara lain: Pertama, Alasan konstitusional merupakan sesuatu yang baru yakni: Hak warga negara untuk memilih yang terdapat di dalam hakhak warga negara yang dijamin Konstitusi berupa persamaan kedudukan di dalam hukum dan pemerintahan yaitu Pasal 27 ayat (1), hak untuk memperoleh pengakuan, jaminan, perlindungan, dan kepastian hukum yang adil serta perlakuan yang sama di hadapan hukum sebagaimana amanat Pasal 28D ayat (1), hak untuk memperoleh kesempatan yang sama dalam pemerintahan sebagaimana Pasal 28D ayat (3); semuanya itu merupakan bentuk dari perwujudan kedaulatan rakyat (Pasal 1 ayat (2) dan Pasal 6A ayat (1).

Kedua, Hak warga negara untuk memilih secara cerdas pada Pemilihan umum serentak ini terkait dengan konsep political efficacy dimana warga negara dapat membangun peta checks and balances dari Pemerintahan Presidensial dengan keyakinannya sendiri.

Ketiga, Hak warga negara untuk memilih secara efisien pada pemilihan umum serentak terkait dengan penggunaan waktu, energi, biaya warga negara untuk melaksanakan Hak Pilihnya yang lebih terjamin dengan penyelenggaraan Pemilihan Umum serentak. Keempat, Pada sisi efisiensi penyelenggaraan pemilihan umum, berdasarkan riset pendahuluan pemohon, perhitungan Pemborosan Penyelenggaraan Pemilu Tidak Serentak (berasal dari APBN dan APBD, dan juga pajak warga negara) bisa berkisar antara 5 hingga 10 Triliun Rupiah dalam hal Pemilu Presiden dan Wakil Presiden dibuat terpisah dengan Pemilu Anggota DPR/D dan DPD; atau sampai berkisar 20 hingga 26 Triliun (karena Pemilu Kepala Daerah tidak dapat dilaksanakan secara serentak pula).

2 Lihat Risalah Rapat Komisi A Sidang Tahunan MPR Tahun 2001 tanggal 4-8 Nopember 2001, pada Rapat Komisi A, Kedua (Lanjutan) tanggal 5 Nopember 2001, lihat juga Dody Nur Andriyan, (2018), Dewan Perwakilan Daerah Republik Indonesia Dalam Perspektif Teori Bicameralisme, Jurnal Volksgeist, IAIN Purwokerto, No. 1 Vol. 1 tahun 2018, hal 79 - 94 
Kelima, Adanya Pemilihan Umum yang dilaksanakan secara serentak akan mendorong partai politik lebih cermat dalam menentukan arah kaderisasinya, apakah ke arah anggota legislatif di tingkat mana, ataukah ke arah Presiden dan Wakil Presiden, dan di masa depan ke arah calon kepala daerah di tingkat mana (sehingga tidak terjadi seorang kader mencoba mencari peruntungan politik di aneka tingkatan pada aneka tahun pemilihan). Keenam, Adanya Pemilihan Umum yang dilaksanakan secara serentak juga sering dikaitkan dengan Penghematan serta Pencegahan korupsi politik, bersamaan dengan Pencegahan politik uang yang bisa mencapai ratusan Triliun.

Pemilu Serentak yang akan dilaksanakan di Indonesia, sebenarnya adalah konsekuensi dari sistem Presidensial (Nuryanti, (2015:130), setidaknya terdapat 4 (empat) pandangan relevansi Pemilu dan Pilkada Serentak: pertama, dari sisi penyelenggaraan Pemilu Serentak mendorong terciptanya efektivitas dan efisiensi. Salah satunya karena dilakukan secara bersama-sama, bahkan apabila nantinya Pemilu Nasional (memilih legislatif dan Presiden/Wapres) di lakukan bersamaan dengan Pilkada (Pemilihan Kepala Daerah). Tentu saja efektivitas akan lebih tercipta. Biaya untuk penyelenggaraan, operasional, honor dan biaya lainnya tentu akan efektif jika Pemilu serentak (legislatif, presiden/wakil presiden dan kepala daerah) berhasil dilaksanakan. Kedua, dari segi proses akan tercipta demokrasi yang berkeadaban (democratic civility) dalam arti terjadinya kerjasama yang baik antara elemen-elemen demokrasi sehingga demokrasi dapat berjalan sesuai cita-citanya yaitu untuk menciptakan keadilan dan kesetaraan didalam masyarakat dan meminimalisir terjadinya benturan kepentingan. Ketiga, dari segi hasil Pemilu Serentak akan menciptakan pemerintahan yang solid dan efektif karena lahir dari proses yang solid dan efektif. Sehingga lebih pro rakyat, memiliki akar yang kuat dengan kekuatan politik local, sekaligus memiliki hubungan yang sinergis dengan pemerintah pusat. Sehingga tentu akan menciptakan otonomi daerah yang lebih baik lagi. Keempat, Pemilu serentak (legislatif, presiden/wakil presiden dan kepala daerah) dari segi birokratis akan menciptakan masa bakti (periodisasi) yang lebih tertata. Antara satu daerah dengan daerah lain akan sinergis, dengan pemerintah pusat dan dengan partai politik akan lebih sinergis, efisiensi birokrasi akan tercipta, perencanaan kerja akan fokus, dan pelaksanaan program pembangunan akan lebih kompak dan serempak. Banyak program pembangunan di daerah yang tersendat dan mangkrak karena tidak kompak, tidak sinkron dengan pemerintah provinsi dan pemerintah pusat salah satunya karena masa kerja yang tidak serempak (Kumolo, 2015:45-46).

\section{Metodologi}

Penelitian ini adalah penelitian Sosio Legal, yaitu suatu studi yang melihat hukum melalui penggabungan antara analisa normatif (norma-norma hukum, yuridis) dan pendekatan ilmu non-hukum (politik, ekonomi, sosial dan budaya). Sifatnya preskriptif yaitu memberi solusi atas permasalahan hukum 
dengan menggabungkan analisa normatif dan pendekatan non-hukum/aspek sosial (Putro, dan Herlambang P Wiratraman, 2015:3-16). Berdasarkan hal tersebut, maka jelas bahwa luaran dari penelitian ini adalah berupa gagasangagasan rekomendasi yang solutif atas permasalahan hukum (politik hukum) di Indonesia terkait dengan Pemilu Serentak dan Sistem Presidensial Multipartai yang dikaitkan dengan proyeksi Indonesia 2045 dalam konteks perencanaan pembangunan nasional Indonesia. Ada empat jenis identifikasi dan pendekatan penelitian normatif yang dipakai dalam penelitian ini yaitu statute approach, conceptual approach, comparative approach, hystorical approach (brahim, 2005:303).

Peraturan perundang-undangan sebagai data sekunder yang diteliti dan dikaji dikumpulkan dengan metode inventarisisasi data. Sedangkan data primer diperoleh melalui beberapa kegiatan Focus Grup Disscusion, diskusi dan wawancara dengan narasumber. Terdapat juga data sekunder penunjang lainnya berupa buku literatur, jurnal ilmiah, artikel, majalah ilmiah, kamus, ensiklopedia. Validasi terhadap data dilakukan dengan menggunakan metode triangulasi data.

Metode analisis yang digunakan adalah metode analisis data deskriptif kualitatif dengan menggunakan model analisis interaktif. Data yang berupa kalimat-kalimat yang dikumpulkan melalui wawancara, dokumen dan lainnya yang sudah disusun secara teratur lalu dianalisis. Inti yang dapat diambil dari analisis interaktif, yaitu pengambilan data, reduksi data, penyajian data, dan penarikan kesimpulan.

Gambar 1. Model Analisis Interaktif Miles dan Huberman

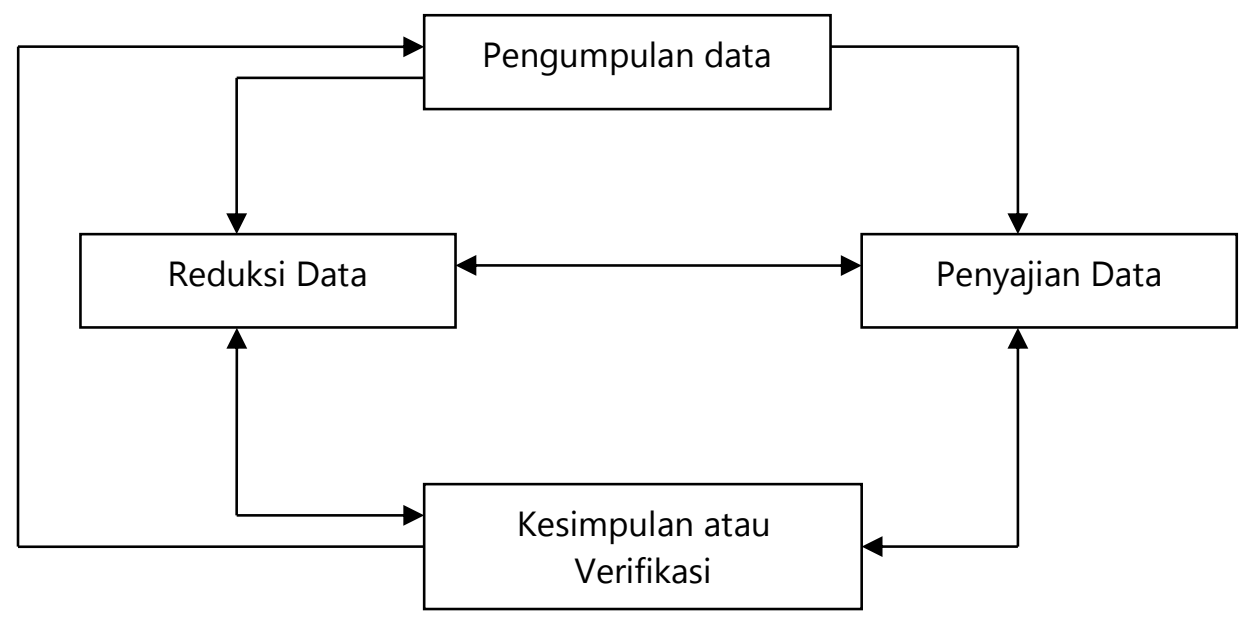

Analisis isi terhadap data sekunder berupa peraturan perundangundangan dilakukan secara hermeneutik, pendekatan atau paradigma ini sering 
juga disebut dengan paradigma interpretatif hermeneutika. ${ }^{3}$ Undang-undang dan peraturan-peraturan juga dianalisis secara kualitatif dan komprehensif. Analisis kualitatif artinya menguraikan bahan secara bermutu dalam bentuk kalimat yang teratur, runtut, logis, tidak tumpang tindih dan efektif, sehingga memudahkan interpretasi data dan pemahaman analisis. Komprehensif artinya analisis data secara mendalam dari berbagai aspek sesuai dengan lingkup penelitian. Lengkap artinya tidak ada bagian yang terlupakan, semuanya masuk dalam analisis (Muhammad, 2004:127).

\section{Hasil Penelitian dan Analisa}

\subsection{Sinergi Pelaksanaan Pemilu Serentak dan Pilkada Serentak}

Untuk bisa mencapai tujuan dari Pemilu serentak, sebagaimana sudah dipaparkan di BAB II, maka Pemilu Serentak (Legislatif dan Presiden) yang diselenggarakan di tahun 2019 seharusnya bersinergi dengan Pilkada Serentak. Pilkada serentak yang saat ini yang tengah berlangsung di Indonesia, sedang memasuki tahapan gelombang ke tiga dari tujuh gelombang Pilkada Serentak. Berdasarkan Pasal 201 Undang-Undang Nomor 8 tahun 2015 tentang Perubahan Atas Undang-Undang Nomor 1 Tahun 2015 Tentang Penetapan Peraturan Pemerintah Pengganti Undang-Undang Nomor 1 Tahun 2014 Tentang Pemilihan Gubernur, Bupati, Dan Walikota Menjadi Undang-Undang, ada 7 (tujuh) gelombang Pilkada Serentak yang diselenggarakan di Indonesia, dalam tabel berikut:

\begin{tabular}{|l|l|l|}
\hline Gelombang & Dilaksanakan Tahun & Untuk Memilih Kepala Daerah \\
\hline Pertama & Desember 2015 & $\begin{array}{l}\text { masa jabatannya berakhir pada } \\
2015 \text { dan semester pertama } \\
2016\end{array}$ \\
\hline Kedua & Februari 2017 & $\begin{array}{l}\text { masa jabatannya berakhir pada } \\
\text { semester kedua 2016 dan 2017 }\end{array}$ \\
\hline Ketiga & Juni 2018 & $\begin{array}{l}\text { masa jabatannya berakhir pada } \\
\text { 2018 dan 2019 }\end{array}$ \\
\hline Keempat & 2020 & hasil pemilihan Desember 2015 \\
\hline
\end{tabular}

3 Hermeneutik metode yang berusaha untuk mengungkapkan dan mengeluarkan perasaanperasaan, motif-motif, dan pemikiran-pemikiran, paradigma, yang ada dalam kegiatan menafsir. Inti dari teori ini adalah bahwa suatu teks bukanlah barang mati yang tidak bisa bercerita, melainkan punya latar belakang dan sejarah, mengapa sampai teks tersebut tertulis seperti itu. Lihat : Richard E Palmer, (2005), Hermeneutika Teori Baru Mengenai Interpretasi, Pustaka Pelajar, Yogyakarta, hal 75, lihat juga Makin, (2001), Paradigma Negara dan Karakteristik Produk Hukum (Studi Terhadap Interprestasi Negara Atas Pasal 28 UUD 1945 Pada Tahun 1967-1998), SKRIPSI Meraih gelar Sarjana Hukum, Fakultas Hukum Universitas Jenderal Soedirman, Purwokerto, Hal 46. 


\begin{tabular}{|l|l|l|}
\hline Kelima & 2022 & $\begin{array}{l}\text { hasil pemilihan pada Februari } \\
2017\end{array}$ \\
\hline Keenam & 2023 & hasil pemilihan 2018 \\
\hline Ketujuh & 2027 & $\begin{array}{l}\text { Pilkada Serentak Nasional } \\
\text { dimulai setiap 5 tahun sekali }\end{array}$ \\
\hline
\end{tabular}

Untuk bisa mencapai tujuan sebagaimana diutarakan dalam BAB II, maka penulis merekomendasikan agar pelaksanaan Pemilu serentak (legislatif dan presiden) digabungkan dengan Pilkada serentak dan itu dapat dilaksanakan pada tahun 2029. Sehingga tujuan dari Indonesia 2045 yang sudah disusun oleh Bappenas, terutama terkait dengan politik dalam negeri dapat tercapai dengan baik. Berikut tabel politik dalam negeri tahapan pencapaian sasaran 2045:

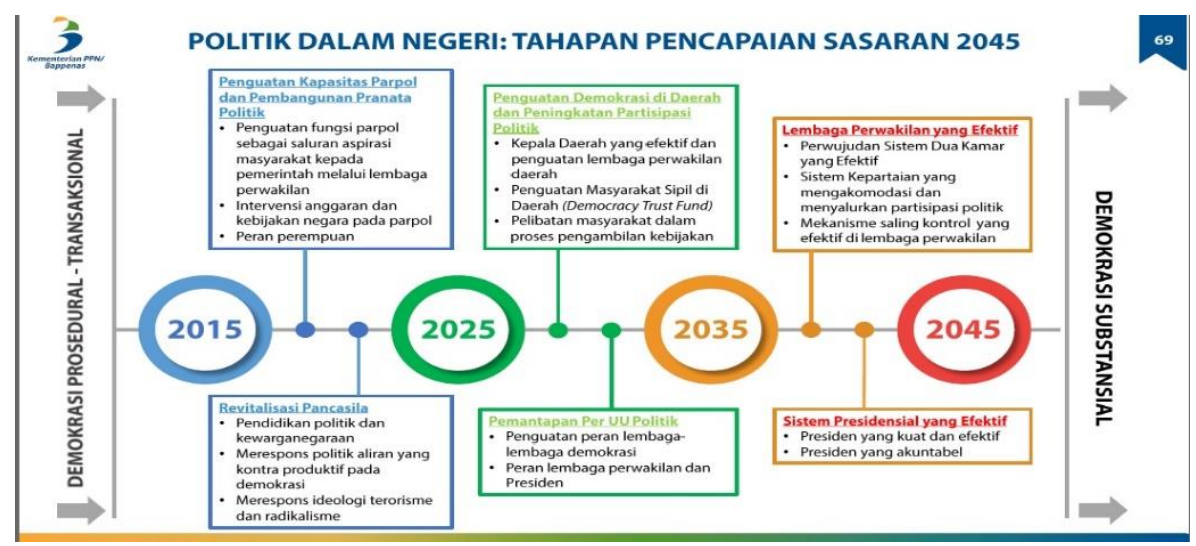

Dengan melakukan sinergi dan pelaksanaan yang serentak dan bersamaan Pemilu legislatif, pemilu presiden dan pemilu kepala daerah pada tahun 2029, maka akan tercapai tujuan penguatan demokrasi di daerah, kepala daerah yang efektif, penguatan lembaga perwakilan didaerah, sekaligus juga penguatan dan pelibatan masyarakat dalam pengambilan keputusan yang sekaligus akan bersinergi dengan sistem presidensial yang efektif dan lembaga perwakilan baik ditingkat daerah dan nasional yang efektif, efisien. Sebagaimana di bahas di BAB II, bahwa waktu yang serentak tersebut akan memberi banyak efek positif.

Oleh karena itu, yang harus dilakukan adalah melakukan perubahan (revisi) Undang-Undang Nomor 8 tahun 2015, dengan memuat pengaturan bahwa Pilkada Serentak akan mulai dilaksanakan pada tahun 2029 (bersamaan dengan Pemilu Serentak Presiden dan Legislatif). Ada beberapa opsi yang penulis ajukan: pertama, jika jarak antara habis masa jabatan kepala daerah sampai dengan tahun 2029 kurang dari 2 tahun, maka dibuat norma untuk memberi perpanjangan masa jabatan kepala daerah sampai dengan 2029, keduajika ternyata jarak dari habis masa jabatan kepala daerah sampai dengan 
tahun 2029 lebih dari 2 tahun maka dibuat norma untuk diangkatnya Pjs (pejabat sementara) sampai dengan pelaksanaan pemilu 2029.

\subsection{Rancangan Undang-Undang Lembaga Peradilan Pemilu Kepala Daerah.}

Pasal 157 ayat (3) UU No. 1 Tahun 2015 junto UU No. 8 Tahun 2015 menyebutkan bahwa "perkara perselisihan penetapan perolehan suara hasil pemilihan diperiksa dan diadili oleh MK sampai dibentuknya badan peradilan khusus".

Kembali menyerahkan sengketa Pilkada kepada MK, jelas berlawanan dengan Putusan MK No. 97/PUU-XI/2013, tanggal 16 Januari 2014. Dalam putusannya, MK menyatakan tidak (lagi) mempunyai kewenangan untuk menyelesaikan perselisihan hasil Pilkada. MK juga menyebut Pilkada bukan bagian dari rezim pemilu. Ini seperti menjadikan MK sebagai lembaga penitipan perkara, suatu kebijakan yang dipaksakan, apalagi bukan sementara. Karena pada Pasal 157 ayat (2) dijelaskan, bahwa badan peradilan khusus baru akan terbentuk sebelum pelaksanaan pemilihan serentak nasional. Maka berarti badan peradilan khusus itu baru akan berfungsi pada Pemilu 2027. Ini dengan asumsi jika penjadwalan pemilu serentak nasional itu akan berjalan lancar.

Gagasan dan rekomendasi yang penulis tawarkan adalah agar DKPP (Dewan Kehormatan Penyelenggara Pemilu) yang diberi kewenangan untuk menjadi Lembaga Peradilan Pemilu Kepala Daerah, dengan waktu yang masih relatif cukup, kita bisa menyusun dan memodifikasi DKPP agar diberi kewenangan sebagai Lembaga Peradilan Pemilu Kepala Daerah.

Terdapat 3 (tiga) alasan yang mendasari urgensitas gagasan ini adalah: Pertama, Penyelesaian Sengketa Pilkada hendaknya jangan diberikan kepada penyelenggara pemilu. KPU dan Bawaslu adalah penyelenggara pemilu. Harus terdapat pemisahan kewenangan antara penyelenggara dan pemutus/pengadil. Kedua, DKPP adalah role model penegakan kode etik abad XXI yang menganut asas fairness, impartiality dan transparency dalam satu model peradilan yang dilaksanakan menurut prinsip "audi et alteram partem". Selain itu, putusan DKPP bersifat final dan mengikat (binding) - sejalan dengan pengadilan sengketa hasil Pilkada yang kewenangannya sudah dijalani MA maupun MK. Ketiga, Melihat sepak terjang dan rekam jejak DKPP, lembaga ini sudah menorehkan catatan dan tinta emas keberhasilan sebagai lembaga pengadilan etika. Baik KPUD, KPU dan Bawaslu ternyata sangat hormat, tunduk dan patuh terhadap putusanputusan DKPP. Pun demikian dengan tingkat kepercayaan dan kepuasan masyarakat terhadap kinerja dan sepak terjang DKPP.

\subsection{Blue Print Rancangan Undang-Undang Lembaga Kepresidenan}

Melanjutkan ide tentang pembentukan lembaga kepresidenan yang dituangkan dalam sebuah Undang-Undang (Andriyan, 2016:199-204), maka urgensitas RUU Lembaga Kepresidenan adalah sebagai berikut: Pertama, Lembaga Kepresidenan secara konstitusional memiliki dasar hukum konstitusi 
yang kuat terdapat dalam BAB III UUD 1945 setelah Amandemen. Kedua, Lembaga Kepresidenan adalah satu-satunya lembaga yang belum mempunyai payung hukum. Dibandingkan dengan DPR, DPD, MPR yang sudah memiliki UU Susduk (UUMD3), BPK yang sudah ada UU nya, MA, MK juga sudah memiliki, bahkan Kementerian dan Dewan Pertimbangan Presiden juga sudah memiliki, maka kebutuhan suatu produk UU yang mengatur tentang Lembaga Kepresidenan juga diperlukan.

Ketiga, dengan adanya UU Lembaga Kepresidenan maka akan bisa diatur dan ditegaskan tupoksi (tugas pokok dan fungsi) Presiden dan Wakil Presiden; Keempat, UU Lembaga Kepresidenan tersebut nantinya juga akan mengatur dan berisi materi muatan tentang koordinasi pembuatan kebijakan seperti Peraturan Pemerintah (PP), Keputusan Presiden (Kepres) dan sejenisnya yang harus di tata ulang. Disinilah letak dari fungsi dan tugas lembaga kepresidenan yang terdiri dari staf ahli yang bertugas me-review dan menelaah semua produk hukum dibawah UU yang merupakan ranah kekuasaan eksekutif untuk membuat aturan operasional, sehingga arah dan langkah legislasi yang dilakukan oleh presiden maupun menteri-menterinya akan bisa tertata dengan baik (Andriyan, 2016:203). Kelima, Melalui UU Lembaga Kepresidenan, maka keberadaan Staf Khusus dan semua perangkat di lembaga kepresidenan juga perlu dilata ulang.

\subsection{Politik Hukum Electoral Threshold, Parlementary Threshold dan Presidential threshold}

Menurut Nohlen terdapat empat kriteria ambang batas. Pertama, persentase; besaran persentase ambang batas yang paling umum antara $3 \%$ (Spanyol) hingga 5\% (Jerman), terendah Belanda 0,67\%, dan yang tertinggi Turki 10\%. Kedua, lokasi penerapan; ketentuan ambang batas diterapkan pada daerah pemilihan (Spanyol), dan diterapkan di tingkat nasional (Jerman), atau di kedua tingkat (daerah pemilihan dan nasional) sekaligus (Swedia). Ketiga, tahap penerapan; ambang batas kebanyakan dilakukan pada tahap awal sebelum penghitungan perolehan kursi, tetapi juga ada yang dilakukan di antara tahapan-tahapan penghitungan perolehan kursi berikutnya (Denmark). Keempat, obyek ambang batas; ambang biasa dikenakan pada setiap partai, tetapi ada juga yang dikenakan kepada koalisi partai (Polandia) (Baldini and Adriano Pappalardo, 2008:32-33).

Mahkamah Konstitusi sendiri sebenarnya juga menyatakan bahwa politik hukum penyederhanaan kepartaian melalui electoral treshold dan parlementary thresold adalah sah dan konstitusional dalam Putusan No 12/PUUVI/2008 dan putusan No 3/PUU-VII/2009. Penerapan konsep electoral treshold perlu dilakukan untuk menyederhanakan partai yang ikut akan ikut pemilu selanjutnya. Dengan penyederhanaan jumlah parpol peserta pemilu akan lebih memudahkan pemilih menentukan pilihan, memberikan kesempatan masyarakat lebih rasional dalam memilih tanpa dibingungkan oleh besaran 
kertas suara yang harus memuat banyaknya parpol peserta pemilu. Pada akhirnya, dengan penyederhanaan jumlah peserta pemilu melalui instrumen electoral treshold akan tercapai kondisi suara yang mendekati mayoritas mutlak, sehingga setidaknya sesuai atau mendekati ideal dengan sistem presidensial (Fahmi, 2016:8). Sedangkan konsep parlementary treshold perlu diterapkan untuk menyederhanakan konfigurasi partai politik yang ada di DPR. Sehingga sistem presidensial Indonesia akan lebih kokoh dan stabil.

Menurut penulis terdapat dua definisi terkait presidential threshold. Definisi pertama, yang dimaksud dengan presidential threshold adalah syarat seorang calon presiden untuk terpilih menjadi presiden. Misalnya di Brazil 50 persen plus satu, di Ekuador 50 persen plus satu atau 45 persen asal beda 10\% dari saingan terkuat; di Argentina 45 persen atau 40 persen asal beda 10\% dari saingan terkuat Payne, Daniel Zobatto G., Fenando Carrillo Flórez, Andrés Allamnd Zavala, 2012:73). Jika definisi ini diterapkan di Indonesia, maka presidential threshold sudah ada didalam Pasal 6 A ayat (3) dan (4) UUD 1945.

Definisi kedua, presidential threshold adalah syarat terpenuhinya jumlah ambang batas suara untuk partai politik yang ingin mengajukan sendiri calonnya di kontestasi Pemilihan Presiden. Ambang batas suara menjadi syarat apakah suatu partai dapat mengajukan sendiri atau harus bergabung dan berkoalisi karena tidak memenuhi ambang batas suara untuk bisa mencalonkan sendiri calon presiden/wakil presiden di Pemilu Presiden.

Definisi yang kedua ini terdapat dalam Pasal 222 Undang-undang Nomor 7 Tahun 2017 tentang Pemilihan Umum (UU Pemilu), partai politik atau gabungan partai politik harus memiliki 20 persen kursi DPR atau 25 persen suara sah nasional pada Pemilu 2014 lalu untuk bisa mengusung pasangan capres dan cawapres.

Dengan demikian, sebenarnya dalam sistem pemerintahan Presidensial Multipartai khususnya di Indonesia (khas Indonesia) memang membutuhkan dan memerlukan ambang batas pencalonan Presiden (Presidential Threshold) dalam rangka untuk menyinergikan Presidensial Multipartai dan konsolidasi demokrasi sehingga tercipta Sistem Presidensial Multipartai yang kuat dan efektif.

\subsection{Perubahan Undang-Undang Pemilu terkait dengan Evaluasi Sistem Pemilu Proposional Dengan Metode Perhitungan Sainte-Laguë}

Sistem pemilu proporsional terbuka dengan model perhitungan SainteLaguë ini akan memberikan efek kepada partai yang memperoleh suara besar di suatu Daerah Pemilihan yang akan diganjar kursi sesuai dengan porsi suaranya, sedangkan partai yang memperoleh suara menengah di suatu Daerah Pemilihan akan ditarik pada garis yang lebih netral. Di dalam sistem ini, identifikasi apakah sebuah partai itu layak disebut partai besar atau partai kecil di tentukan di Daerah Pemilihan. Hal ini disebabkan karena "penghitungan perolehan suara-kursi dihabiskan di Daerah Pemilihan". Bisa saja suatu partai di 
tingkat nasional dikualifikasi sebagai partai besar, namun belum tentu di suatu Daerah Pemilihan. Begitu juga sebaliknya, suatu partai di tingkat nasional yang dikualifikasi menengah atau kecil, bisa saja di suatu Daerah Pemilihan malah jadi partai besar.

Metode Sainte-Lague bukan tanpa cela dan kritik, metode SainteLague dalam penghitungan suara hasil pemilu sangat proporsional. Dengan demikian metode ini memberikan keuntungan kepada partai kecil atau partai baru. Kesempatan terbuka lebar kepada partai kecil untuk memperoleh kursi karena memang suara akan habis di bagi di Daerah Pemilihan. Dengan demikian, pemilu akan memunculkan banyak partai baru yang akan ikut mencalonkan diri. Pertama, tentu saja akan menyulitkan tujuan awal pemilu serentak presidensial multipartai yaitu menciptakan keselarasan dan keseimbangan sekaligus penyederhanaan kepartaian. Kedua, partai-partai baru yang muncul karena diuntungkan dengan metode Sainte Lague dikhawatirkan hanya akan mengambil keuntungan untuk memperoleh kedudukan karena mereka mempunyai kesempatan yang besar untuk mendapatkan kursi dan kurang diimbangi dengan kinerja dan kontribusi yang baik dalam menjalankan tugasnya kelak.

\section{Kesimpulan dan Rekomendasi}

Bahwa konstruksi ketatanegaraan Indonesia Pasca Amandemen I-IV UUD 1945 mempunyai format untuk memperkuat dan menegaskan sistem presidensial multipartai yang disinergikan dengan pelaksanaan pemilu presiden, pemilu legislatif, dan pemilu kepala daerah secara serentak. Oleh karenanya berdasarkan hal tersebut, agar tercapai tujuan dari visi Indonesia 2045 perlu dilakukan langkah-langkah strategis sebagai berikut: 1) Menyinergikan Pemilu Presiden, Pemilu Legislatif dan Pemilu Kepala Daerah secara serentak di 2029; 2) Menyusun Rancangan Undang-Undang Lembaga Peradilan Pemilu Kepala Daerah; 3) Membuat blue print Rancangan Undang-Undang Lembaga Kepresidenan; 4). Melakukan penyederhanaan sistem kepartaian dengan electoral threshold, 5). Melakukan penyederhanaan jumlah partai di parlemen dengan parlementary threshold; 6). Menerapkan presidential threshold agar tercipta keseimbangan didalam sistem presidensial multipartai; 7). Melakukan perubahan Undang-Undang Pemilu dan Evaluasi sistem Pemilu Proposional dengan metode perhitungan Sainte-Laguë.

VI. Daftar Pustaka

Buku Literatur

Andriyan, Dody Nur, (2016), Hukum Tata Negara dan Slstem Politik: Kombinasi Presidensial dengan Multipartai di Indonesia, Deepublish, Yogyakarta

Baldini, Gianfranco, and Adriano Pappalardo, (2008), Elections, Electoral Systems and Volatile Voters, New York: Palgrave Macmillan 
Budiardjo, Miriam, (2008), Dasar-Dasar IImu Politik (Edisi Revisi), Jakarta, Gramedia Pustaka Utama

Fahmi, Khairul, (2016), Pemilihan Umum dalam Transisi Demokrasi Kompilasi Catatan Atas Dinamika Pemilu dan Pilkada di Era Demokrasi, Jakarta, Raja Grafindo Persada

Ibrahim, Johnny, (2005), Teori dan Metodologi Penelitian Hukum Normatif, Bayumedia, Malang

Kumolo, Tjahjo, (2015), Politik Hukum Pilkada Serentak, Bandung, Mizan Publika Lijphart, Arend, (1995), Sistem Pemerintahan Parlementer dan Presidensial, (terjemahan) Grafika Persada, Jakarta,

Makin, (2001), Paradigma Negara dan Karakteristik Produk Hukum (Studi Terhadap Interprestasi Negara Atas Pasal 28 UUD 1945 Pada Tahun 1967-1998), SKRIPSI Meraih gelar Sarjana Hukum, Fakultas Hukum Universitas Jenderal Soedirman, Purwokerto

Monstesquieu, (2007), The Spirit of Laws: Dasar-Dasar IImu Hukum dan IImu Politik (Terjemahan: The Spirit Of Laws, University of California Press, 1977), Nusamedia, Bandung

Muhammad, Abdulkadir, (2004), Hukum dan Penelitian Hukum, Citra Aditya Bakti, Bandung

Palmer, Richard E, (2005), Hermeneutika Teori Baru Mengenai Interpretasi, Pustaka Pelajar, Yogyakarta

Payne, J. Mark, Daniel Zobatto G., Fenando Carrillo Flórez, Andrés Allamnd Zavala (2012) "Democracies in Development: Politics and Reform in Latin America", Washington D.C., The Inter-American Development Bank and the International Institue for Democracy and Electoral Assitance, The John Hopkins University Press.

Jurnal IImiah

Andriyan, Dody Nur, (2018), Dewan Perwakilan Daerah Republik Indonesia Dalam Perspektif Teori Bicameralisme, Jurnal Volksgeist, IAIN Purwokerto, No. 1 Vol. 1 tahun 2018

Hanan, Djayadi, (2016), Memperkuat Presidensialisme Multipartai di Indonesia: Pemilu Serentak, Sistem Pemilu, dan Sistem Kepartaian, Jurnal Universitas Paramadina Vol. 13 Tahun 2016

Nazriyah, R., (2015), Pengaturan Pelaksanaan Pemilihan Kepala Daerah Serentak, Jurnal Hukum lus Quia lustum No. 1 Vol. 22 Januari 2015

Nuryanti, Sri, (2015), Intervensi Penyelenggaraan Pemilukada: Regulasi, Sumberdaya dan Eksekusi, Jurnal Ilmu Sosial dan Ilmu Politik, Volume 19, Nomor 2, November 2015

Putro, Widodo D, dan Herlambang P Wiratraman, (2015), Penelitian Hukum, Antara Yang Normatif dan Empiris. Digest Epistema, Vol. V Tahun 2015. 
Peraturan Perundang-undangan dan Putusan Pengadilan

Republik Indonesia, Undang-Undang Dasar 1945 Amandemen I-IV

Undang-Undang Nomor 8 tahun 2015 tentang Perubahan Atas UndangUndang Nomor 1 Tahun 2015 Tentang Penetapan Peraturan Pemerintah Pengganti Undang-Undang Nomor 1 Tahun 2014 Tentang Pemilihan Gubernur, Bupati, Dan Walikota Menjadi Undang-Undang

Republik Indonesia, Undang-undang Nomor 7 Tahun 2017 tentang Pemilihan Umum

Putusan Mahkamah Konstitusi Nomor 14/PUU-XI/2013

Putusan Mahkamah Konstitusi Nomor 97/PUU-XI/2013

Putusan Mahkamah Konstitusi Nomor 12/PUU-VI/2008

Putusan Mahkamah Konstitusi Nomor 3/PUU-VII/2009.

Lain-Lain

Menteri Perencanaan Pembangunan Nasional/Kepala Badan Perencanaan Pembangunan Nasional, (2017), Visi Indonesia 2045, Jakarta, 30 Mei 2017

Risalah Rapat Komisi A Sidang Tahunan MPR Tahun 2001 tanggal 4-8 Nopember 2001, pada Rapat Komisi A, Kedua (Lanjutan) tanggal 5 Nopember 2001, 